The London

A study in the Voluntary Hospital System, Vol. I, I 740-I 840. A. E. ClaRK-KENNEDY, M.D., F.R.C.P. Pp. 264, illustrated. London: Pitman Medical. 1962.

Anyone who was fortunate enough to be taught by Dr. Clark-Kennedy at Cambridge or the London Hospital will always remember the enthusiasm and unique personal touch with which he approached any subject. These qualities are clearly discernible in this book. Such a history could easily have been a rather dull catalogue of facts but Dr. Clark-Kennedy guides us through a century of struggles, hardships and triumphs in the East End of London with so much skill that we are not aware of the passage of time. It is his description of the social conditions in which the hospital developed and of the personalities of the staff, be they porters or consultants, which makes the history so interesting.

It is easy to imagine, in these days when hospitals are such complex institutions, that our committees face problems more difficult than ever before; the London Hospital committees of the 18 th century certainly were spared most of our technicalities but they appear to have had just as much trouble dealing with the appalling problems arising from bed bugs, inadequate sewage, drunkenness and lack of trained staff. The early pioneers of the Voluntary Hospital System had to be strong and determined to achieve their aims and it is not surprising that there were occasional conflicts amongst the senior members of the staff.

Every aspect of hospital life is sympathetically presented and, after reading this book, one is left with much gratitude to the many individuals who created this great hospital, often with so little personal reward. The next volume of the history is eagerly awaited.

Principles of the Treatment of Trauma: Basic Principles, Plastic and Orthopedic Aspects of Trauma

Edited by W. H. Kirkaldy-Willis and A. Michael Wood. Pp. xi +244 , illustrated. Edinburgh and London: E. \&.S. Livingstone. 1962. 42s.

This book does not claim to be a textbook on the management of trauma, but it does try to single out certain principles of treatment and to indicate their physiological and pathological basis. It is written primarily for medical officers in the smaller hospitals of the younger countries, and also in the hope that it may be of some use to interns, residents and registrars the world over.

The authors are to be congratulated on a new and arresting approach. The first chapter lists eight surgical disasters and makes constructive comments on their prevention. The remainder of the book is an expansion of these comments. The basic principles of fluid and electrolyte therapy and tissue repair are adequately discussed and there is a chapter on chemotherapy with special reference to the problems of treatment in the absence of a bacteriological service.

The treatment of burns is dealt with in some detail and includes the management of ectropion and other contractures because this type of injury represents one of the major surgical problems in the under-developed areas. The principles of wound closure, and especially the treatment of the neglected and septic wound, are jikewise fully described.

Fractures and joint injuries of the upper and lower limbs are summarized with special reference to the pitfalls in treatment and the indications for referral to fully equipped surgical centre. No opportunity is los to hammer home the vital importance of physiotherapyD in the rehabilitation of all types of injury and trouble is taken to describe the exercises advised. The book ends. with a short masterly discussion of spinal fractures.

The book is well produced and illustrated and there? is a useful list of references at the end of each chaptero It should be of value to all who find themselves no를 within easy reach of a major hospital.

\section{Clinical Neurosurgery}

Proceedings of the roth Congress of Neurologica $\vec{P}$ Surgeons, Chicago, Illinois, 1960. Vol. 8. Baltimore Williams and Wilkins. London: Baillière, TindalW and Cox. 1962. 96s.

This volume is devoted to the physiology and surgery of the spinal cord. There are 15 chapters, each ant individualistic essay not claiming to be a comprehensive review of the subject, with the notable exception of at splendid account by Guy Odom of vascular abnormalities in and around the spinal cord. In this chapter ninein spontaneous spinal hæmorrhages-epidural, subarach $-\mathrm{W}$ noid and intramedullary - are described resulting from arterial, venous, capillary and arterio-venous malformations, and the frequently progressive disability due to 7 such lesions without hæmorrhage is emphasized.

Professor Paul Bucy, the guest of honour at this congress in 1960, continues to denigrate our belovedE. pyramidal tract. Though he admits that it is probably $-\overrightarrow{0}$ the most important neural pathway responsible fo efficient movement of the skeletal muscles, he denses that it is the only one, for there is good anatomicat evidence of the existence of other pathways, ext pyramidal at least in the brain, relaying in the basals ganglia.

Bucy writes two other chapters-one ' A Philosophy of̆ Neurosurgery ', in which he condemns the inhumanity of preserving life at all costs, and one a report on two of the less common spinal tumours-vertebral giant cell tumour and primary epidural lymphosarcoma, both 3 with examples of survival many years after decom? pressive operation and radiotherapy.

The chapters on lumbar disc protrusions and on high cervical cordotomy are confirmatory of standara American practice, with local anæsthesia and restricteof. exposure. (I note that after experience of 5,000 cases of lumbar protrusions the Tennessee school do not use routine myelography.)

There are useful short chapters by Matson on con genital spinal defects, by Turnbull on intramedullaryo tumours and by Campbell on late operations for incontinence due to spinal maldevelopments, but few British neurosurgeons would accept entirely the extensive list of indications for operation on cases of traumation paraplegia offered by Schneider.

Other articles on the pain pathways, regeneration after spinal cord section and on the psychiatric aspects of paim are for idle reading with rewarding interest now and then, but fortunately the very long chapter on cervicap discs need not be read at all, for the operation of insertingo a dowel of bone by the anterior route between two adjacent cervical vertebræ after rummaging abouts between them and waiving the trachea and oesophagus aside will not survive. This chapter could well have been replaced by, perhaps, a discussion on spina? arachnoiditis, an important subject omitted entirely. 